Harris, W. J. (1955). J. gen. Microbiol. 13, 103-4.

\title{
Demonstration of the Existence of Spore Sacs around Resting Spores of Bacillus subtilis and Bacillus globigii
}

\author{
By W. J. HARRIS \\ Chemical Defence Experimental Establishment, Ministry of Supply, \\ Porton, Wiltshire
}

Up to the present time, it has not been shown conclusively that germinating spores possess sacs before germination commences. However, in the course of an electron microscope study of the spores of Bacillus subtilis and B. globigii evidence has been obtained to show the existence of well-defined sacs around resting spores.

Complete spore sacs, similar to those vacated by germinated spores, have been stripped from a proportion of freeze-dried spores subjected to high gas pressure subsequently quickly released. The method employed was somewhat similar to that used by Fraser (1951) for bursting bacteria, but the pressure of the gas (nitrogen) was higher $\left(1500 \mathrm{lb} . /\right.$ in. $\left.^{2}\right)$ and the release almost instantaneous. This was achieved by the rupture of a metal diaphragm incorporated in the cylinder containing the spores (method devised by $\mathbf{M r} \mathbf{J}$. Edwards.)

The micrographs obtained also illustrate distinct differences in the physical characteristics of the spore sacs of Bacillus subtilis and B. globigii (cf. Lamanna, 1940). Pl. 1, fig. 1 shows empty spore sacs of $B$. subtilis vacated by germinated spores, and Pl. 1, fig. 2, a typical example of a sac removed by quick release of gas pressure. In both cases the sac appears to be a hard structure strengthened in the polar regions and having a central region of weakness where rupture always occurs. The spore sac of $\boldsymbol{B}$. globigii, however, appears to be a soft flimsy structure with a pronounced weakness at one pole where rupture always takes place, whether during germination (Pl. 1, fig. 3) or as a result of quick release of gas pressure (Pl. 1, fig. 4). Evidence obtained indicates that after polar rupture by the latter process in $\boldsymbol{B}$. globigii spores, sac removal is caused by fragmental tearing (Pl. 1, fig. 5).

Acknowledgement is made to the Chief Scientist, Ministry of Supply, for permission to publish this note.

\section{REFERENCES}

Fraser, D. (1951). Bursting bacteria by release of gas pressure. Nature, Lond. 167, 33.

Lamanna, C. (1940). The taxonomy of the genus Bacillus. Modes of spore germination. J. Bact. 40, 347. 


\section{EXPLANATION OF PLATE}

Fig. 1. Spore sacs of $B$. subtilis vacated by germinated spores; $\times 10,000$.

Fig. 2. Field showing spore sac of $B$. subtilis removed by quick release of gas pressure; $\times 10,000$.

Fig. 3. Germinated spore of $B$. globigii; $\times 10,000$.

Fig. 4. Spore sac of $B$. globigii removed by quick release of gas pressure; $\times 10,000$.

Fig. 5. Illustration of the mechanism of spore sac removal in $B$. globigii by quick release of gas pressure; $\times 10,000$.

(Received 13 January 1955) 
Journal of General Microbiology, Vol. 13, No. 1
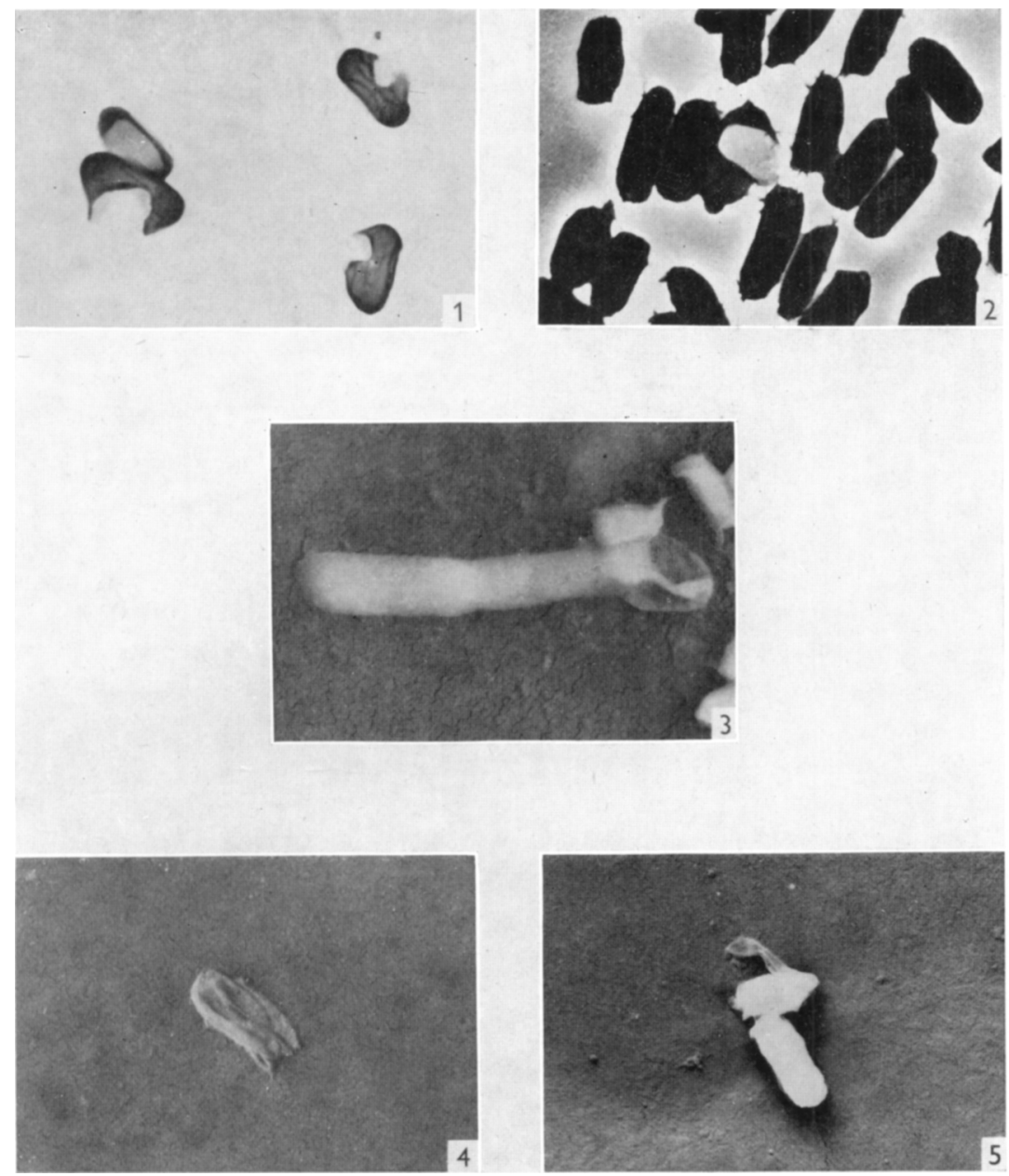

W. J. HARRIS-EXISTENCE OF SPORE SACS IN BACILLUS SUBTILIS AND BACILLUS globigil Plate 1 